\title{
Effect of Physiologic Hyperinsulinemia on Glucose and Lipid Metabolism in Cirrhosis
}

\author{
Alexander S. Petrides, Leif C. Groop, Caroline A. Riely, and Ralph A. DeFronzo \\ Division of Gastroenterology and Hepatology, Department of Medicine, Heinrich-Heine Universitat Dusseldorf, Germany; \\ and Division of Diabetes, Department of Medicine, University of Texas Health Science Center. \\ and Audie L. Murphy Veterans Administration Hospital, San Antonio, Texas 78284
}

\begin{abstract}
Insulin secretion and insulin sensitivity were evaluated in eight clinically stable cirrhotic patients and in 12 controls. OGTT was normal in cirrhotics but plasma insulin response was increased approximately twofold compared with controls. Subjects received a three-step $(0.1,0.5,1.0 \mathrm{mU} / \mathrm{kg} \cdot \mathrm{min})$ euglycemic insulin clamp with indirect calorimetry, $\left[6-{ }^{3} \mathrm{H}\right]$-glucose, and $\left[1-{ }^{14} \mathrm{C}\right]$-palmitate. During the two highest insulin infusion steps glucose uptake was impaired $(3.33 \pm 0.31$ vs. $5.06 \pm 0.40 \mathrm{mg} /$ $\mathrm{kg} \cdot \mathrm{min}, P<0.01$, and $6.09 \pm 0.50$ vs. $7.95 \pm 0.52 \mathrm{mg} / \mathrm{kg} \cdot \mathrm{min}, P$ $<0.01$ ). Stimulation of glucose oxidation by insulin was normal; in contrast, nonoxidative glucose disposal (i.e., glycogen synthesis) was markedly reduced. Fasting $(r=-0.553, P$ $<0.01)$ and glucose-stimulated $(r=-0.592, P<0.01)$ plasma insulin concentration correlated inversely with the severity of insulin resistance. Basal hepatic glucose production was normal in cirrhotics and suppressed normally with insulin. In postabsorptive state, plasma FFA conc $(933 \pm 42$ vs. $711 \pm 44 \mu \mathrm{mol} /$ liter, $P<0.01)$ and FFA turnover $(9.08 \pm 1.20$ vs. $6.03 \pm 0.53$ $\mu \mathrm{mol} / \mathrm{kg} \cdot \min , P<0.01)$ were elevated in cirrhotics despite basal hyperinsulinemia; basal FFA oxidation was similar in cirrhotic and control subjects. With low-dose insulin infusion, plasma FFA oxidation and turnover failed to suppress normally in cirrhotics. During the two higher insulin infusion steps, all parameters of FFA metabolism suppressed normally. In summary, stable cirrhotic patients with normal glucose tolerance exhibit marked insulin resistance secondary to the impaired nonoxidative glucose disposal. Our results suggest that chronic hyperinsulinism may be responsible for the insulin resistance observed in cirrhosis. (J. Clin. Invest. 1991. 88:561-570.) Key words: insulin resistance $\cdot$ hyperinsulinemia $\bullet$ glucose $\bullet$ free fatty acid cirrhosis
\end{abstract}

\section{Introduction}

The majority of patients with cirrhosis develop glucose intolerance and some $10-15 \%$ develop overt diabetes mellitus $(1,2)$. Because most of these patients exhibit increased peripheral

Address correspondence to Ralph A. DeFronzo, M.D., Professor of Medicine, Diabetes Division, Dept. of Medicine, University of Texas Health Science Center, 7703 Floyd Curl Drive, San Antonio, TX 78284.

Dr. Riely's present address is Division of Hepatology, Dept. of Medicine, University of Memphis, Memphis, TN 38163.

Received for publication 9 March 1990 and in revised form 11 January 1991.

J. Clin. Invest.

(C) The American Society for Clinical Investigation, Inc. 0021-9738/91/08/0561/10 $\$ 2.00$

Volume 88, August 1991, 561-570 plasma insulin levels $(3,4)$, the presence of resistance to the action of insulin has been suggested and this has been documented in several recent studies (5-8). However, the etiology of the defect(s) in insulin-mediated glucose metabolism in cirrhosis have yet to be defined. From the quantitative standpoint the liver and peripheral (muscle) tissues represent the two most important organs responsible for insulin action on overall glucose homeostasis in man $(9,10)$. During euglycemic insulin clamp studies $80-85 \%$ of the infused glucose is taken up by muscle (9). Using this technique, total body glucose uptake has been shown to be reduced by $40-50 \%$ in cirrhotic subjects when examined at high physiologic insulin levels (5-8). The mechanism (i.e., oxidative versus nonoxidative disposal), however, of the impairment of insulin action in cirrhosis remains to be defined.

The ability of high physiologic $(>55 \mu \mathrm{U} / \mathrm{ml})(7,11)$ or pharmacological (7) plasma insulin concentrations to suppress hepatic glucose production (HGP) ${ }^{1}$ has been shown to be normal in cirrhosis. However, the suppression of HGP is essentially complete at plasma insulin levels $>50-60 \mu \mathrm{U} / \mathrm{ml}$ and an increment of only 5-10 $\mu \mathrm{U} / \mathrm{ml}$ has been shown to cause a $40-60 \%$ decline in hepatic glucose output (10). To our knowledge, no one has examined the effect of insulin on HGP within the physiologic range in patients with cirrhosis.

With respect to insulin-mediated glucose uptake by peripheral tissues, it is possible that a shift in substrate utilization from glucose to lipid, i.e., the Randle cycle (12) is responsible for the defect in insulin action. Plasma free fatty acid (FFA) levels and lipid oxidation rates have been reported to be increased in cirrhosis (13-15) and it is possible that an increased rate of lipid oxidation is responsible, in part, for the impairment in insulin-mediated glucose disposal.

In the present study we have employed the euglycemic clamp technique in combination with indirect calorimetry and infusion of $\left[6-{ }^{3} \mathrm{H}\right]$-glucose and $\left[1-{ }^{14} \mathrm{C}\right]$-palmitate to examine the effects of physiologic increments in the plasma insulin concentration on oxidative and nonoxidative glucose disposal, suppression of HGP, and plasma FFA turnover. The studies were carried out in cirrhotic patients who had mild to moderate hepatic insufficiency (Child A) and whose condition was stable in order to exclude changes in nutritional intake and total body composition; in addition, we measured lean body mass which primarily reflects muscle, the tissue which is responsible for glucose disposal under hyperinsulinemic conditions. Our results indicate that both insulin-mediated suppression of plasma FFA turnover/oxidation and stimulation of glucose disposal are impaired in cirrhosis but that these two defects are unrelated.

1. Abbreviations used in this paper: FFA, free fatty acid; HGP, hepatic glucose production; OGTT, oral glucose tolerance test. 


\section{Methods}

\section{Subjects}

Eight cirrhotic patients (four male, four female) were studied. Their physical characteristics, Child's classification (16), diagnosis, and laboratory data are displayed in Table I. In seven patients the diagnosis was confirmed by biopsy, whereas in one patient (No. 4) the diagnosis was based upon clinical grounds. As documented by long-term followup (2-10 yr) all patients were in stable condition according to the following criteria: no evidence of ascites or peripheral edema and no gastrointestinal bleeding for at least $1 \mathrm{yr}$. Serum sodium, potassium, and creatinine concentrations were normal in all patients. No patients were taking any medications at the time of the study. All patients were engaged in normal physical activity and were neither excessively sedentary or active. All subjects ingested a balanced diet (50\% carbohydrates, $35 \%$ fat, and $15 \%$ protein), containing at least $200 \mathrm{~g}$ of carbohydrates per day, for $3 \mathrm{~d}$ before study. Patients with cirrhosis due to excessive alcohol consumption had been off alcohol for at least 1 yr. 12 subjects (eight males, four females), matched for age and body weight served as controls (Table I). None of the subjects had any history of diabetes or major organ disease other than hepatic cirrhosis. Before their participation, the nature, purpose, and risks of the study were explained to all subjects and their voluntary, informed, written consent was obtained. The experimental protocol was approved by the Human Investigation Committee of Yale University School of Medicine, and the University of Texas Health Science Center.

\section{Experimental protocol}

Each subject participated in two studies which were performed within a 4-7-d interval.

\section{ORAL GLUCOSE TOLERANCE TEST}

After a 10-12-h overnight fast, a 75-g oral glucose load was given at $0800 \mathrm{~h}$ and blood was taken at $-20,-10,-5,0,30,60,90$, and 120 min for determination of plasma glucose, insulin, and FFA concentrations. At time 0 of the oral glucose tolerance test (OGTT), $10 \mathrm{ml}$ of blood was drawn and a bolus injection of $60 \mu \mathrm{Ci}$ of ${ }^{3} \mathrm{H}_{2} \mathrm{O}$ (New England Nuclear, Boston, MA) was administered. At 80, 100, and 120 min after the bolus injection, when steady-state conditions were achieved, $5 \mathrm{ml}$ of blood was drawn for analysis of ${ }^{3} \mathrm{H}_{2} \mathrm{O}$ radioactivity and used to determine lean body mass.

\section{EUGLYCEMIC INSULIN CLAMP STUDY}

All studies were performed at $0800 \mathrm{~h}$ after a $10-12$-h overnight fast. Before study, one catheter was placed into an antecubital vein for the infusion of all test substances; a second catheter was inserted retrogradely into a wrist vein for blood sampling. The hand then was inserted into a heated box $\left(70^{\circ} \mathrm{C}\right)$ to achieve arterialization of venous blood. At $0800 \mathrm{~h}$ prime continuous infusions of $\left[6-{ }^{3} \mathrm{H}\right]$-glucose and $\left[1-{ }^{14} \mathrm{C}\right]-$ palmitate were initiated as described below. At 0930-, 0940-, 0950-, and 1000 -h baseline samples for plasma hormone, substrate, and radioactivity were obtained. At $1000 \mathrm{~h}$ a three-step euglycemic insulin (infusion rates $=0.1,0.5,1.0 \mathrm{mU} / \mathrm{kg} \cdot \mathrm{min}),($ Eli Lilly Co., Indianapolis, IN)

Table I. Summary of Patients' Characteristics

\begin{tabular}{|c|c|c|c|c|c|c|c|c|c|c|c|c|c|}
\hline \multirow[b]{2}{*}{ Diagnosis } & \multicolumn{5}{|c|}{ Laboratory data } & \multicolumn{8}{|c|}{ Physical characteristics } \\
\hline & Albumin & Bilirubin & SGOT & PT & $\mathrm{Hgb}$ & Sex & Age & Height & Weight & IBW & SA & LBM & FFM \\
\hline & $g / d l$ & $m g / d l$ & U/liter & & $g / d l$ & & $v r$ & $\mathrm{~cm}$ & $k g$ & $\%$ & $m^{2}$ & $k g$ & \% of body wt \\
\hline \multicolumn{14}{|l|}{ Cirrhotics } \\
\hline Laennec & 3.8 & 0.88 & 68 & $12.4 / 11.7$ & 14.4 & $\mathbf{m}$ & 44 & 169 & 75 & 113 & 1.85 & 51.4 & 68.5 \\
\hline Postnecrotic & 3.8 & 0.80 & 16 & $12.4 / 12.0$ & 11.7 & f & 66 & 169 & 59 & 94 & 1.67 & 40.9 & 69.3 \\
\hline Postnecrotic & 4.4 & 0.86 & 204 & $10.7 / 11.6$ & 15.3 & f & 52 & 158 & 51 & 90 & 1.50 & 41.3 & 81.8 \\
\hline Laennec & 4.5 & 1.18 & 36 & $11.4 / 11.9$ & 15.1 & $\mathbf{m}$ & 55 & 177 & 72 & 102 & 1.88 & 57.4 & 79.7 \\
\hline Laennec & 3.9 & 0.85 & 32 & $11.6 / 11.3$ & 14.4 & f & 57 & 159 & 52 & 90 & 1.52 & 40.3 & 77.5 \\
\hline Idiopathic & 3.9 & 0.42 & 64 & $12.4 / 11.6$ & 11.1 & $\mathbf{m}$ & 48 & 184 & 90 & 120 & 2.13 & 64.6 & 71.9 \\
\hline Laennec & 3.6 & 1.03 & 64 & $12.0 / 10.7$ & 15.1 & $\mathbf{m}$ & 39 & 178 & 104 & 146 & 2.21 & 77.4 & 74.2 \\
\hline \multirow[t]{2}{*}{ Postnecrotic } & 3.9 & 1.48 & 36 & $10.9 / 11.0$ & 13.1 & f & 54 & 170 & 74 & 117 & 1.85 & 51.4 & 69.5 \\
\hline & & & & & & Mean & 52 & 171 & 72 & 109 & 1.83 & 53.1 & 74.1 \\
\hline \multirow[t]{14}{*}{ Controls } & & & & & & m & 42 & 185 & 83 & 110 & 2.06 & 61.0 & 73.5 \\
\hline & & & & & & f & 69 & 171 & 61 & 96 & 1.71 & 41.3 & 67.7 \\
\hline & & & & & & m & 51 & 165 & 63 & 98 & 1.69 & 44.9 & 71.3 \\
\hline & & & & & & m & 55 & 174 & 66 & 95 & 1.79 & 45.0 & 68.2 \\
\hline & & & & & & f & 56 & 161 & 54 & 92 & 1.55 & 41.8 & 78.7 \\
\hline & & & & & & m & 48 & 170 & 71 & 106 & 1.82 & 48.7 & 74.1 \\
\hline & & & & & & f & 44 & 170 & 86 & 136 & 1.97 & 55.2 & 64.2 \\
\hline & & & & & & $\mathbf{m}$ & 48 & 183 & 83 & 114 & 2.04 & 66.3 & 79.9 \\
\hline & & & & & & $\mathbf{m}$ & 68 & 160 & 69 & 110 & 1.72 & 38.1 & 56.9 \\
\hline & & & & & & f & 33 & 163 & 61 & 102 & 1.65 & 40.0 & 65.6 \\
\hline & & & & & & $\mathrm{m}$ & 34 & 175 & 81 & 116 & 1.96 & 67.4 & 83.2 \\
\hline & & & & & & $\mathbf{m}$ & 61 & 173 & 79 & 115 & 1.92 & 52.9 & 67.0 \\
\hline & & & & & & Mean & 51 & 171 & 71 & 108 & 1.82 & 50.2 & 70.0 \\
\hline & & & & & & \pm SEM & 4 & 2 & 3 & 4 & 0.05 & 3.0 & 2.2 \\
\hline
\end{tabular}

All subjects were Child's A classification. IBW, ideal body weight; SA, surface area; LBM, lean body mass; FFM, fat free mass; PT, prothrombin time (patient/control); Hgb, hemoglobin; SGOT, serum glutamate oxaloacetate transaminase. Normal ranges for control subjects are: albumin (3.7-4.8), bilirubin (< 1.50), SGOT (15-35), hemoglobin (13-16). 
clamp was performed. Each insulin infusion step lasted $100 \mathrm{~min}$. The plasma glucose concentration was maintained constant at the basal preinfusion level by determination of the plasma glucose concentration every $5 \mathrm{~min}$ and appropriate adjustment of a $20 \%$ glucose solution based upon the negative feedback principle (17). Under steady-state conditions of constant euglycemia, all of the infused glucose must be taken up by tissues. Thus, the exogenous glucose infusion rate, when added to the endogenous rate of residual HGP, provides a measure of the total amount of glucose metabolized by the entire body. Blood samples for determination of plasma hormone, substrate, and radioactivity were drawn at 20-30-min intervals throughout the insulin clamp.

At $0800 \mathrm{~h}$ before beginning the insulin clamp boluses of $\left[6-{ }^{3} \mathrm{H}\right]-$ glucose $(25 \mu \mathrm{Ci})$ (New England Nuclear) and $\left[1{ }^{14} \mathrm{C}\right]$-palmitate $(2 \mu \mathrm{Ci})$ (New England Nuclear) were rapidly injected and constant infusions of $\left[6-{ }^{3} \mathrm{H}\right]$-glucose $(0.25 \mu \mathrm{Ci} / \mathrm{min})$ and $\left[1-{ }^{14} \mathrm{C}\right]$-palmitate $(0.1 \mu \mathrm{Ci} / \mathrm{min})$ were begun and continued until the end of the insulin clamp study. The labeled FFA was supplied in toluene and, after drying under nitrogen, it was resuspended in $25 \%$ human serum albumin. To prime the bicarbonate pool, a bolus injection of $\left[1-{ }^{14} \mathrm{C}\right]$-bicarbonate $(3.7 \mu \mathrm{Ci})(\mathrm{New}$ England Nuclear) also was given at the beginning of the study. During the basal period and during the last $30 \mathrm{~min}$ of each insulin clamp step, when substrate and isotopic steady-state conditions were achieved, plasma samples were drawn every 5 min for determination of tritiated glucose and ${ }^{14} \mathrm{C}$-FFA specific activity. Steady-state conditions of ${ }^{14} \mathrm{C}$ palmitate were achieved during the last $30 \mathrm{~min}$ of each insulin infusion step.

\section{Respiratory gas exchange measurements}

For 60 min before initiation of the three-step insulin clamp study and during the last $60 \mathrm{~min}$ of each step, continuous indirect calorimetry was performed as previously described (9). A transparent plastic ventilated hood was placed over the head of the subject and made airtight around the neck. A slight negative pressure was maintained in the hood to avoid loss of expired air. Ventilation was measured by means of a dry gas meter (American Meter Division, Singer Co., Philadelphia, PA). A constant fraction of the air flowing out of the hood was automatically collected for analysis. The oxygen content was continuously measured by electrochemical analysis (model S-3A oxygen analyzer; Applied Electrochemistry, Inc., Sunnyvale, CA) and carbon dioxide content by an infrared analyzer (model CD 3A Carbon Dioxide analyzer; Applied Electrochemistry, Inc.). The amount of protein oxidized during the study was calculated from the urinary nitrogen excretion (18).

\section{EXPIRED AIR COLLECTION}

The rate of plasma FFA oxidation was calculated from the specific activity of expired $\mathrm{CO}_{2}$ during the $\left[1-{ }^{14} \mathrm{C}\right]$-palmitate infusion (see below). Expired air samples were collected at 5-min intervals during the last $20 \mathrm{~min}$ of the baseline period and each clamp step and bubbled through a carbon dioxide trapping solution (hyamine hydroxide:absolute ethanol:0.1\% phenolphthalein, 3:5:1). The solution was titrated to trap $1 \mathrm{mmol}$ of $\mathrm{CO}_{2}$ per $3 \mathrm{ml}$ of solution. The ${ }^{14} \mathrm{C}$-radioactivity was subsequently determined using a Tricarb Scintillation Counter (Packard Instrument Co., Inc., Downers Grove, IL) and the expired ${ }^{14} \mathrm{CO}_{2}$ specific activity calculated. Total ${ }^{14} \mathrm{CO}_{2}$ expired per minute was determined by multiplying the ${ }^{14} \mathrm{CO}_{2}$ specific activity by the total amount of $\mathrm{CO}_{2}$ produced as measured by indirect calorimetry.

\section{ANALYTICAL DETERMINATIONS}

Plasma glucose concentration was determined by the glucose oxidase method on a Glucose Analyzer II (Beckman Instruments, Inc., Fullerton, CA). Methods for determination of plasma tritiated glucose and plasma tritiated water specific activities have been published previously $(19,20)$. Plasma insulin (21), glucagon (22), and growth hormone (23) concentrations were measured by specific radioimmunoassays. Plasma epinephrine and norepinephrine concentrations were measured by a radioenzymatic method (24). Urinary nitrogen excretion was determined by the method of Kjeldahl (18). Plasma FFA concentrations were measured by the microfluorometric method of Miles et al. (25)
For the determination of ${ }^{14} \mathrm{C}$-FFA specific activity, $1.5 \mathrm{ml}$ of plasma was extracted with $10 \mathrm{ml}$ of Doles solution. FFA were isolated from the lipid phase using $0.02 \mathrm{~N} \mathrm{NaOH}$ and reextracted after acidification with heptane. The heptane extraction was repeated three times and $90 \%$ of the radioactivity was recovered in the heptane phase. The extracts were dissolved in Scintiverse scintillation liquid and counted in a Tricarb Scintillation Counter (model 320; Packard Instrument Co., Inc.).

\section{CALCULATIONS}

Glucose and insulin metabolism. During the stepwise insulin clamp studies, the glucose infusion rate was determined by calculating the mean value observed during selected time intervals. For data presentation, the mean of the last $60 \mathrm{~min}$ of each insulin infusion step was used. Total glucose metabolism was calculated by adding the mean rate of endogenous glucose production during the last $60 \mathrm{~min}$ of each insulin infusion step to the mean glucose infusion rate during the same period. In all studies, a steady-state plateau of tritiated glucose specific activity was achieved during the $30 \mathrm{~min}$ before starating the insulin clamp. Glucose production in the basal state was determined by dividing the $\left[6-{ }^{3} \mathrm{H}\right]$-glucose infusion rate by the steady-state plateau of $\left[6-{ }^{3} \mathrm{H}\right]-$ glucose specific activity achieved during the last $30 \mathrm{~min}$ of the preinsulin infusion control period. After glucose/insulin administration, a nonsteady-state condition in glucose specific activity exists and hepatic glucose production was calculated by using Steele's equations in their derivative form (26); this permits the evaluation of continuous changes in the rates of glucose turnover. The value of 0.65 was used as the pool fraction in the present calculations (27). Negative numbers for hepatic glucose production, which were observed in 10 of 12 control subjects and 4 of 8 cirrhotic subjects during the $1 \mathrm{mU} / \mathrm{min} \cdot \mathrm{kg}$ insulin clamp study, were treated as zero. The rate of endogenous glucose production was calculated by substracting the glucose infusion rate from the rate of glucose appearance $\left(R_{\mathrm{a}}\right)$, as determined by the isotopic tracer technique.

Glucose oxidation was calculated from continuous calorimetric measurements during the last $40 \mathrm{~min}$ in the basal state and during the last $\mathbf{4 0}$ min of each insulin infusion step, as previously described (28) and are expressed in milligrams per kilogram - minute. Nonoxidative glucose disposal was calculated by substracting the rate of glucose oxidation from the rate of total body glucose uptake. The metabolic clearance rate of insulin was calculated by dividing the insulin infusion rate by the increment in plasma insulin concentration above baseline.

Lipid metabolism. Total lipid oxidation was calculated from continuous indirect calorimetric measurements in the basal state and during the last $\mathbf{4 0} \mathrm{min}$ of each insulin step as previously described (28). To allow direct comparison with ${ }^{14} \mathrm{C}$-FFA oxidation, total lipid oxidation (in milligrams) has been converted to moles by dividing by the molecular weight of palmitate (mol wt 256). Because palmitoyl-oleyl-steatoryltriglyceride contains glycerol, total lipid oxidation, expressed as oxidation of FFA, will be overestimated. The difference would be $<4 \%$ if pure palmitate and $<1 \%$ if pure oleate were oxidized. Energy expenditure was calculated as described in reference 29.

Plasma FFA concentration and turnover. The plasma FFA concentration and specific activity were constant during the last $30 \mathrm{~min}$ of the basal equilibration period and during the last $40 \mathrm{~min}$ of each insulin clamp stem. Therefore, steady-state conditions were assumed to calculate rates of FFA turnover. Palmitic acid accounts for $\sim 30 \%$ of the total FFA pool, and this percentage is independent of the total plasma FFA concentration (30). Because palmitate has been shown to be representative of other long-chain fatty acids in healthy man $(30,31)$ and in cirrhotic patients (13), the fractional turnover of palmitate can be assumed to be similar to that of total FFA. Therefore, labeled palmitate can be used to trace the total FFA fraction when studying whole-body FFA turnover. The total rate of plasma FFA turnover was calculated as the palmitate infusion rate divided by the steady-state plasma FFA specific activity and is expressed as micromoles per kilogram - minute. It should be noted that the present tracer ${ }^{14} \mathrm{C}$-palmitate infusion protocol differed significantly from that employed by previous investigators $(32,33)$. To achieve a steady state of ${ }^{14} \mathrm{CO}_{2}$ specific activity in expired 
air more quickly, we administered a bolus of palmitate and primed the bicarbonate pool with $\left[{ }^{14} \mathrm{C}\right]-\mathrm{NaHCO}_{3}(34)$. A steady-state plateau of plasma $\left[{ }^{14} \mathrm{C}\right]$-FFA and ${ }^{14} \mathrm{CO}_{2}$ specific activity was achieved during the basal state and during the last $40 \mathrm{~min}$ of each insulin clamp step. Therefore, we have used steady-state kinetics in the calculation of both the rate of plasma FFA turnover and the rate of plasma FFA oxidation.

The rate of oxidation of plasma FFA in the basal state and during the euglycemic insulin clamp was calculated from the ${ }^{14} \mathrm{C}$-radioactivity in expired $\mathrm{CO}_{2}$ divided by the product of the plasma specific activity and a factor $k$ which takes into account the incomplete recovery of labeled ${ }^{14} \mathrm{CO}_{2}$ from the bicarbonate pool $(32,34)$. Thus, the plasma FFA oxidation rate (micromoles per kilogram - minute) equals: (SA $\left.\mathrm{CO}_{2}\right) \times \mathrm{VCO}_{2} / k \times\left(\mathrm{SA}^{14} \mathrm{C}\right.$-FFA $)$, where $\mathrm{SA}^{14} \mathrm{CO}_{2}$ is the specific activity of $\mathrm{CO}_{2}$ in expired air; $\mathrm{VCO}_{2}$ is the total $\mathrm{CO}_{2}$ production, $\mathrm{SA}{ }^{14} \mathrm{C}$-FFA is the specific activity of ${ }^{14} \mathrm{C}$-FFA in plasma, and $k=0.81$. Nonoxidative FFA disposal, which serves as a measure of reesterification of FFA, was calculated as the difference between plasma total FFA turnover and plasma FFA oxidation (35).

Lean body mass. Total body water (TBW) was calculated from the dilution of the bolus of tritiated water $(20,36)$ as follows: TBW $={ }^{3} \mathrm{H}_{2} \mathrm{O}$ bolus $(\mathrm{dpm}) /{ }^{3} \mathrm{H}_{2} \mathrm{O}$ concentration in plasma, where plasma water is assumed to represent $93 \%$ of plasma volume. Lean body mass (LBM) is then estimated as follows: $\mathrm{LBM}=\mathrm{TBW} / 0.73$, where 0.73 is the ratio of TBW to LBM.

Statistical analysis. All data are presented as the mean \pm SEM. The significance of difference between the two groups was assessed using analysis of variance.

\section{Results}

Patient characteristics (Table I). Lean body mass, fat free mass, and ideal body weight (based upon medium framed individuals from the 1983 Metropolitan Life Insurance Tables) were similar in cirrhotic and control individuals (Table I).

OGTT (Fig. 1). Cirrhotic patients as a group had slightly, although not significantly higher plasma glucose levels during the OGTT than controls. Both the fasting $(P<0.01)$ and postglucose $(P<0.01)$ plasma insulin levels were markedly elevated in the cirrhotic group. Fasting plasma FFA levels were significantly elevated in cirrhotic patients but suppressed normally after oral glucose ingestion (Fig. 1). There was no relationship between the basal plasma FFA concentration and either the fasting insulin level or the insulin concentration during the OGTT.

Plasma substrate and hormone concentrations during the insulin clamp. The fasting plasma glucose concentrations were similar in cirrhotic and control subjects $(88 \pm 6 \mathrm{vs} .89 \pm 4 \mathrm{mg} / \mathrm{dl})$ and were maintained close to the basal level during the threestep insulin clamp in both groups with coefficients of variation of $3.9 \pm 0.5 \%$ and $3.7 \pm 0.5 \%$, respectively. Cirrhotic patients exhibited fasting hyperinsulinemia $(16 \pm 4$ vs. $7 \pm 1 \mu \mathrm{U} / \mathrm{ml}, P$ $<0.02$ ) but the increment in plasma insulin concentration during each of the three insulin clamp steps was similar in both groups (Fig. 2). Consequently, there was no difference in the metabolic clearance rate of insulin between cirrhotic and control groups during any of the insulin clamp steps.

Plasma glucagon, norepinephrine, epinephrine, and growth hormone concentrations. Basal plasma glucagon concentration was slightly but not significantly elevated in cirrhotic versus control subjects $(205 \pm 87$ vs. $90 \pm 12 \mathrm{pg} / \mathrm{ml}, P=\mathrm{NS})$. During the $1 \mathrm{mU} / \mathrm{kg} \cdot \mathrm{min}$ insulin clamp study the absolute plasma glucagon concentration decreased by $\sim 20 \%$ in both groups $(160 \pm 80$ vs. $72 \pm 15 \mathrm{pg} / \mathrm{ml})$. The plasma norepinephrine concentrations during the postabsorptive state (335 \pm 49 vs. $185 \pm 18 \mathrm{pg} / \mathrm{ml}$ ) and during the $1 \mathrm{mU} / \mathrm{kg} \cdot \mathrm{min}$ insulin clamp step $(395 \pm 81$ vs. $235 \pm 30 \mathrm{pg} / \mathrm{ml})$ were significantly higher $(P$ $<0.01)$ in cirrhotic than in control subjects. Plasma epinephrine concentrations during the basal state $(25 \pm 5$ vs. $28 \pm 4 \mathrm{pg} /$ $\mathrm{ml}$ ) and $1 \mathrm{mU} / \mathrm{kg} \cdot \mathrm{min}$ insulin clamp step were similar in cirrhotic and control subjects. Plasma growth hormone concentration could only be obtained in the basal period and was similar in cirrhotic and control subjects $(1.3 \pm 0.2$ vs. $1.7 \pm 0.2$ $\mathrm{ng} / \mathrm{ml})$.

Glucose metabolism. In the basal state the rate of total body glucose disposal equals the rate of glucose appearance (HGP) and was similar in the cirrhotic $(1.74 \pm 0.07 \mathrm{mg} / \mathrm{kg} \cdot \mathrm{min})$ and control $(1.92 \pm 0.09 \mathrm{mg} / \mathrm{kg} \cdot \mathrm{min})$ subjects. There was no significant enhancement of glucose uptake during the $0.1 \mathrm{mU} /$ $\mathrm{kg} \cdot \mathrm{min}$ insulin clamp in either the control or cirrhotic group. During the two higher insulin infusion steps total body glucose uptake was significantly impaired in cirrhotic versus control subjects $(0.5 \mathrm{mU} / \mathrm{kg} \cdot \min : 3.33 \pm 0.31$ vs. $5.06 \pm 0.40 \mathrm{mg} /$ $\mathrm{kg} \cdot \min , P<0.01 ; 1 \mathrm{mU} / \mathrm{kg} \cdot \min : 6.09 \pm 0.50$ vs. $7.95 \pm 0.50$ $\mathrm{mg} / \mathrm{kg} \cdot \min , P<0.01 ;$ Fig. 2 ).

The rate of glucose oxidation in the postabsorptive state was $1.25 \pm 0.15 \mathrm{mg} / \mathrm{kg} \cdot \mathrm{min}$ in cirrhotic patients and $1.24 \pm 0.19$ $\mathrm{mg} / \mathrm{kg} \cdot \mathrm{min}$ in controls $(P=\mathrm{NS}, \mathrm{Fig} .3)$. No increase in glucose oxidation was observed in either cirrhotic or control subjects during low-dose insulin infusion. During the 0.5 and $1.0 \mathrm{mU} /$ $\mathrm{kg} \cdot \mathrm{min}$ insulin clamp studies the increase in glucose oxidation was similar in cirrhotic and control subjects (Fig. 3). Nonoxidative glucose disposal (NOGD) was similar in cirrhotic and control subjects during the basal state and failed to increase during the $0.1 \mathrm{mU} / \mathrm{kg} \cdot \mathrm{min}$ insulin clamp. During both the $0.5 \mathrm{mU} /$ $\mathrm{kg} \cdot \min (1.18 \pm 0.29$ vs. $3.05 \pm 0.43 \mathrm{mg} / \mathrm{kg} \cdot \min )$ and $1.0 \mathrm{mU} /$ $\mathrm{kg} \cdot \min (3.30 \pm 0.36 \mathrm{vs} .5 .29 \pm 0.57 \mathrm{mg} / \mathrm{kg} \cdot \mathrm{min})$ insulin clamp
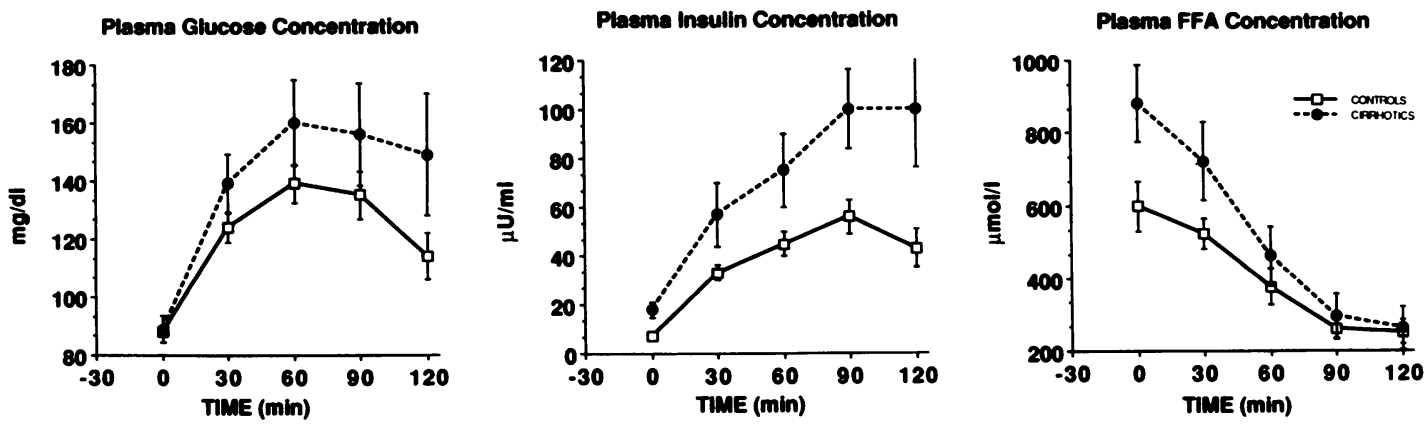

Figure 1. Plasma glucose, insulin, and FFA concentrations during the OGTT in cirrhotic (open squares) and control (solid circles) subjects. The mean areas under all three curves were significantly increased $(P<0.05)$ in cirrhotic vs. control subjects. 

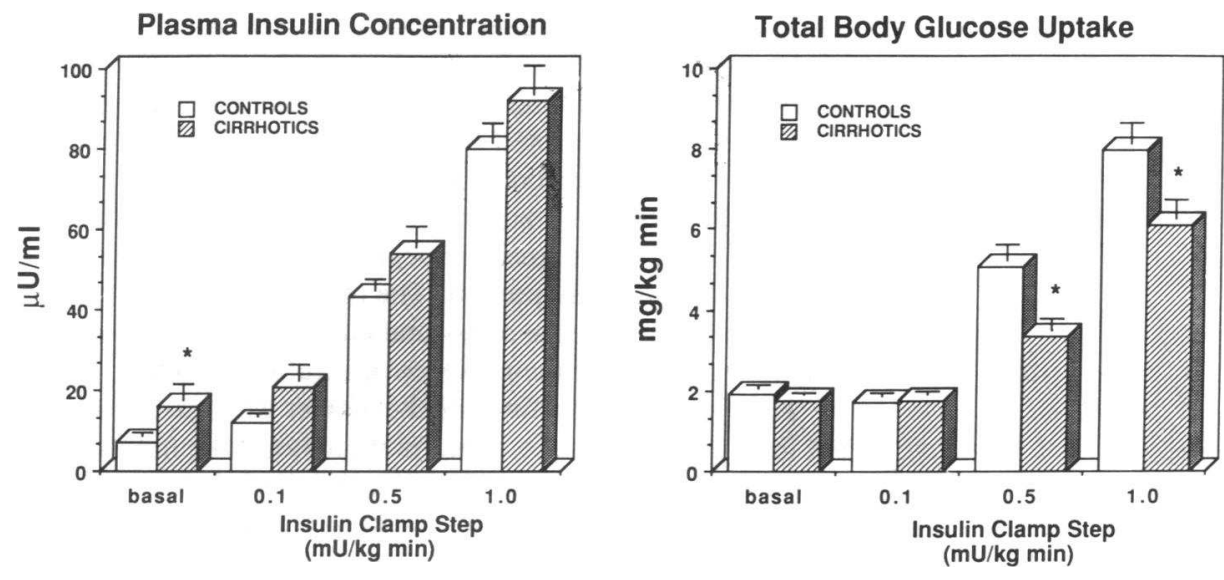

Figure 2. Plasma insulin concentration (upper panel) and total body glucose uptake (lower panel) in cirrhotic (crosshatched bars) and control (open bars) subjects in the basal state and during the three-step insulin clamp. All values represent the mean \pm SEM. ${ }^{*} P<0.01$. steps NOGD was significantly decreased in cirrhotic compared to control subjects $(P<0.01)$ and completely accounted for the defect in total body insulin-mediated glucose uptake.

Basal HGP, as well as HGP during each of the three insulin clamp steps, was similar in cirrhotic and control subjects (Fig. 4). The mean insulin response during OGTT was inversely correlated with the rate of total body glucose disposal during the $0.5 \mathrm{mU} / \mathrm{kg} \cdot \min (r=-0.64), P<0.05)$ and $1.0 \mathrm{mU} /$ $\mathrm{kg} \cdot \min (r=-0.58, P<0.01)$ insulin clamp steps (Fig. 5). The fasting plasma insulin concentration also was inversely correlated with the rate of total body glucose disposal during the 0.5 $\mathrm{mU} / \mathrm{kg} \cdot \min (r=-0.53, P<0.05)$ and $1.0 \mathrm{mU} / \mathrm{kg} \cdot \min (r$ $=-0.51, P<0.05)$ insulin clamp steps.

Plasma FFA concentration, turnover, and oxidation. In the basal state, the plasma FFA concentration was significantly elevated in cirrhotic versus control individuals $(933 \pm 42$ vs. $711 \pm 44 \mu \mathrm{mol} /$ liter, $P<0.01$, Fig. 6). In response to low-dose insulin infusion, the plasma FFA concentration declined by a similar amount in both cirrhotics and controls but the absolute levels remained higher in the cirrhotic group (566 \pm 88 vs. $351 \pm 34 \mu \mathrm{mol} / \mathrm{liter}, P<0.02$, Fig. 6). At the two higher insulin concentrations circulating FFA levels were suppressed to the same extent in both groups. The plasma FFA turnover rate mirrored the behavior of the plasma FFA concentration (Fig. 6). In cirrhotics, the basal FFA turnover rate was significantly increased $(9.08 \pm 1.2$ vs. $6.03 \pm 0.53 \mu \mathrm{mol} / \mathrm{kg} \cdot \min , P<0.01)$. During the lowest dose insulin infusion the decrement in plasma FFA turnover in cirrhotic and control subjects was similar but the absolute values remained higher in the former $(6.15 \pm 0.91$ vs. $3.51 \pm 0.41 \mu \mathrm{mol} / \mathrm{kg} \cdot \min , P<0.02)$. At the two higher insulin infusion rates, FFA turnover decreased to similar levels in cirrhotic and control subjects (Fig. 6). There was no difference in the plasma FFA oxidation rate in the postabsorptive period between the cirrhotic and the control group $(1.90 \pm 0.26$ vs. $1.74 \pm 0.14 \mu \mathrm{mol} / \mathrm{kg} \cdot \min , P=\mathrm{NS})$. During the lower insulin infusion step insulin failed to suppress FFA oxidation normally in the cirrhotic patients $(14 \%$ decline from baseline in cirrhotics vs. $39 \%$ in controls, $P<0.05$, Fig. 6). At the two higher insulin infusion rates, suppression of plasma FFA oxidation was similar in both groups. In the basal state, $7.18 \pm 0.97 \mu \mathrm{mol} / \mathrm{kg} \cdot \mathrm{min}$ or $80 \%$ of total plasma FFA turnover in cirrhotics compared to $4.28 \pm 0.55 \mu \mathrm{mol} / \mathrm{kg} \cdot \min$ or $70 \%$ in controls was metabolized by nonoxidative pathways indicating that reesterification plays a major role in FFA removal in both groups in the postabsorptive state (Fig. 6). When viewed in absolute terms the cirrhotic subjects showed an increased rate of nonoxidative FFA disposal in the basal state and during low-dose insulin infusion $(P<0.01$, Fig. 6$)$. During the two higher insulin infusion rates, nonoxidative FFA disposal was similar in both groups.

Total body lipid oxidation. In the basal state no difference in total body lipid oxidation (indirect calorimetry) was observed between cirrhotic and control subjects $(3.40 \pm 0.47$ vs. $3.32 \pm 0.43 \mu \mathrm{mol} / \mathrm{kg} \cdot \mathrm{min}, P=\mathrm{NS}$, Fig. 7). In both cirrhotic and
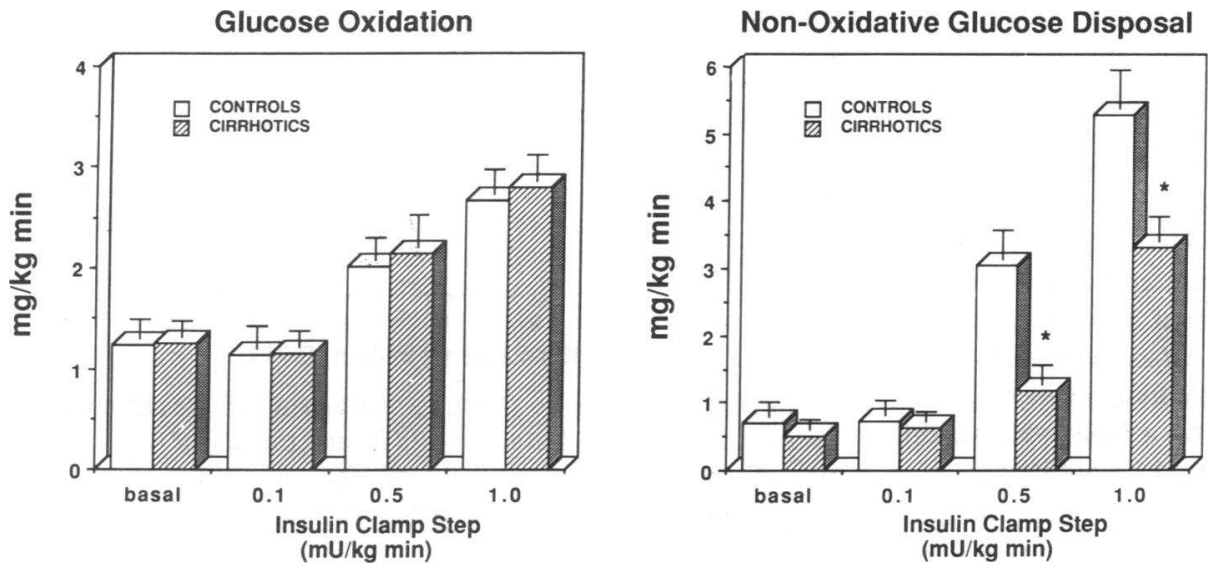

Figure 3. Glucose oxidation (upper panel) and nonoxidative glucose disposal (lower panel) in cirrhotic (crosshatched bars) and control (open bars) subjects in the basal state and during the three-step insulin clamp. All values represent the mean \pm SEM. ${ }^{*} P<0.01$. 


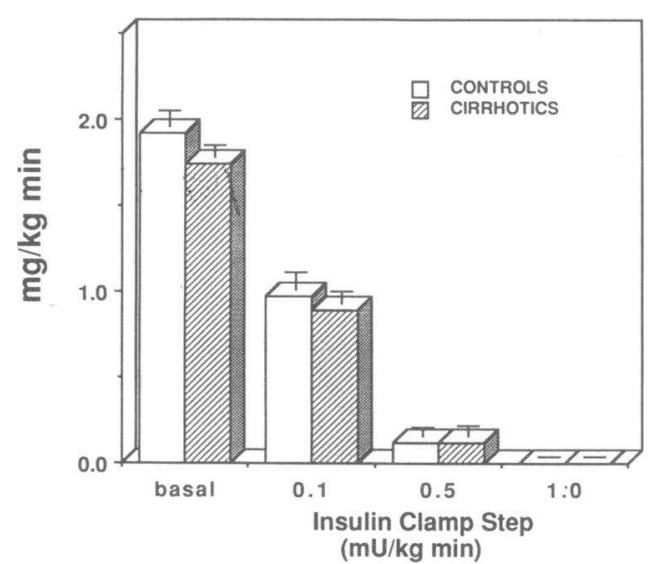

Figure 4. Hepatic glucose production in cirrhotic (cross-hatched bars) and control (open bars) subjects in the basal state and during the three-step insulin clamp. All values represent the mean \pm SEM.

control groups the rate of total body lipid oxidation was $\sim 40$ $50 \%$ greater than could be accounted for by the rate of plasma oxidation. Total lipid oxidation remained unchanged during the lowest insulin infusion step and declined similarly in both groups during the two higher insulin infusions.

Protein oxidation, respiratory quotient, and energy expenditure. The rate of protein oxidation $(0.59 \pm 0.10 \mathrm{vs.} 0.68 \pm 0.06$ $\mathrm{mg} / \mathrm{kg} \cdot \mathrm{min}$ ), the nonprotein respiratory quotient (NPRQ) $(0.82 \pm 0.05$ vs. $0.84 \pm 0.10)$ and energy expenditure $(16.1 \pm 0.6$ vs. $15.9 \pm 0.5 \mathrm{cal} / \mathrm{kg} \cdot \mathrm{min})$ in the basal state was similar in cirrhotic and control subjects. During the $1.0 \mathrm{mU} / \mathrm{kg} \cdot \mathrm{min}$ insulin clamp study, the NPRQ increased to $0.93 \pm 0.08$ vs. $0.93 \pm 0.08$, respectively, in cirrhotics and controls while the rate of energy expenditure rose to $18.0 \pm 0.9$ vs. $17.3 \pm 0.6 \mathrm{cal} /$ $\mathrm{kg} \cdot \min ($ all $P=\mathrm{NS})$.

\section{Discussion}

Cirrhotic patients manifest glucose intolerance $(1,2)$, an abnormal plasma lipid profile (13-15), and impaired insulin-mediated glucose disposal (5-8). However, none of these previous studies attempted to examine whether the disturbances in glucose and lipid metabolism were related, nor did they examine the lower, more physiologic portion of the plasma insulin (10$50 \mu \mathrm{U} / \mathrm{ml}$ ) dose response curve where the suppressive effect of insulin on hepatic glucose production and FFA turnover are maximal. Moreover, most of these earlier studies failed to take into account the severity of the liver disease, alterations in dietary intake, and body composition $(13,37)$. To circumvent these problems, we studied cirrhotic individuals in clinically stable condition with mild to moderate liver disease (Child A classification). We also measured lean body mass, which primarily reflects muscle, the tissue responsible for the majority of glucose disposal during hyperinsulinemic euglycemic conditions $(10,38)$. No patient had evidence of fluid retention or other signs of hepatic decompensation. An exercise history revealed all subjects to be normally active. A dietary history documented that all subjects were consuming a balanced, weight maintaining diet during the 2-3-mo period before study.

In the most general sense the maintenance of normal glucose tolerance is dependent upon three mechanisms that must occur in a tightly coordinated fashion: $(a)$ secretion of insulin by the pancreatic beta cells; $(b)$ suppression of HGP; and (c) insulin-mediated stimulation of glucose uptake by peripheral tissues, primarily muscle (9). During the OGTT the plasma insulin response in cirrhotic subjects was twofold greater than in controls, suggesting that insulin secretion is enhanced and/ or impaired hepatic insulin degradation or portasystemic shunting of insulin are present. The markedly elevated plasma insulin levels in the face of normal glucose tolerance provides indirect evidence for the presence of insulin resistance.

The two major insulin-sensitive tissues which are responsible for the maintenance of normal glucose tolerance are the liver and muscle $(10,38)$. These tissues display very different dose-response characteristics with the $1 / 2 V_{\max }$ for suppression of HGP being much less than that for stimulation of tissue glucose uptake (28). Because the insulin levels employed in previous studies $(7,11)$ were above those that produce a 80 $90 \%$ suppression of hepatic glucose output, a defect of insulin's effect on HGP could have been overlooked. In the present study we employed lower, more physiologic insulin infusion rates to examine hepatic sensitivity in cirrhotic patients. During all three insulin clamp steps HGP suppressed normally in the cirrhotic group. From Fig. 4 it can be appreciated that an increment in plasma insulin conc of only $5-10 \mu \mathrm{U} / \mathrm{ml}$ caused a $50 \%$ suppression of hepatic glucose output in the cirrhotic subjects despite higher circulating plasma glucagon levels. These results indicate that hepatic sensitivity to insulin is not impaired in patients with mild to moderate cirrhosis.

Although, some concern has been raised about the use of tritiated glucose to quantitate rates of glucose appearance and disappearance under nonsteady-state conditions $(34,39-44)$, we do not believe that this could lead to a significant quantitative or qualitative error in estimating hepatic glucose production during the low-dose insulin infusion $(0.1 \mathrm{mU} / \mathrm{kg} \cdot \mathrm{min})$. In previously published studies (41), as well as in unpublished observations, we have shown that the tracer closely approximates the rate of total body $R_{\mathrm{a}}$ and $R_{\mathrm{d}}$ when the glucose metabolic rate does not exceed $\sim 4 \mathrm{mg} / \mathrm{kg} \cdot \mathrm{min}$. During the 0.1 $\mathrm{mU} / \mathrm{kg} \cdot \mathrm{min}$ insulin clamp study, total glucose metabolism did not increase above the basal value. Consequently, one would

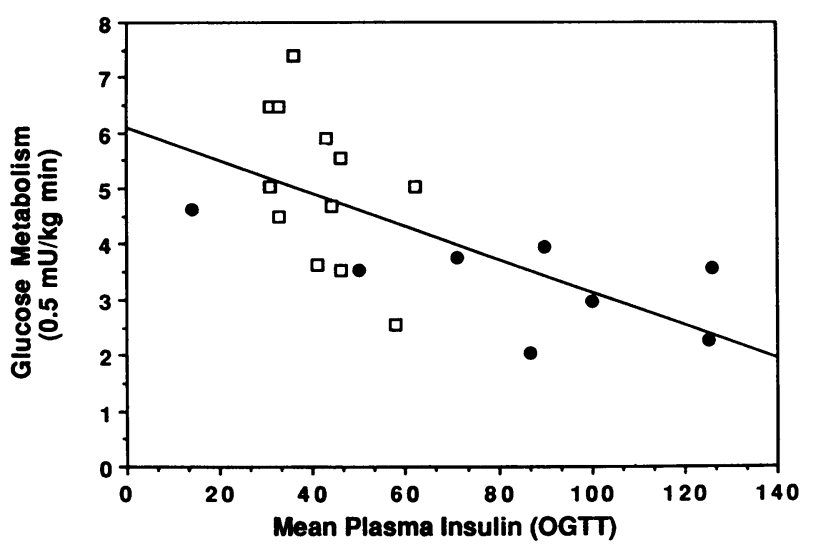

Figure 5. Correlation $(r=-0.64, P<0.01)$ between the mean plasma insulin concentration during the OGTT and the rate of total body glucose metabolism during the $0.5 \mathrm{mU} / \mathrm{kg} \cdot \mathrm{min}$ insulin clamp step. Controls are shown by the open squares and cirrhotics by the solid circles. 

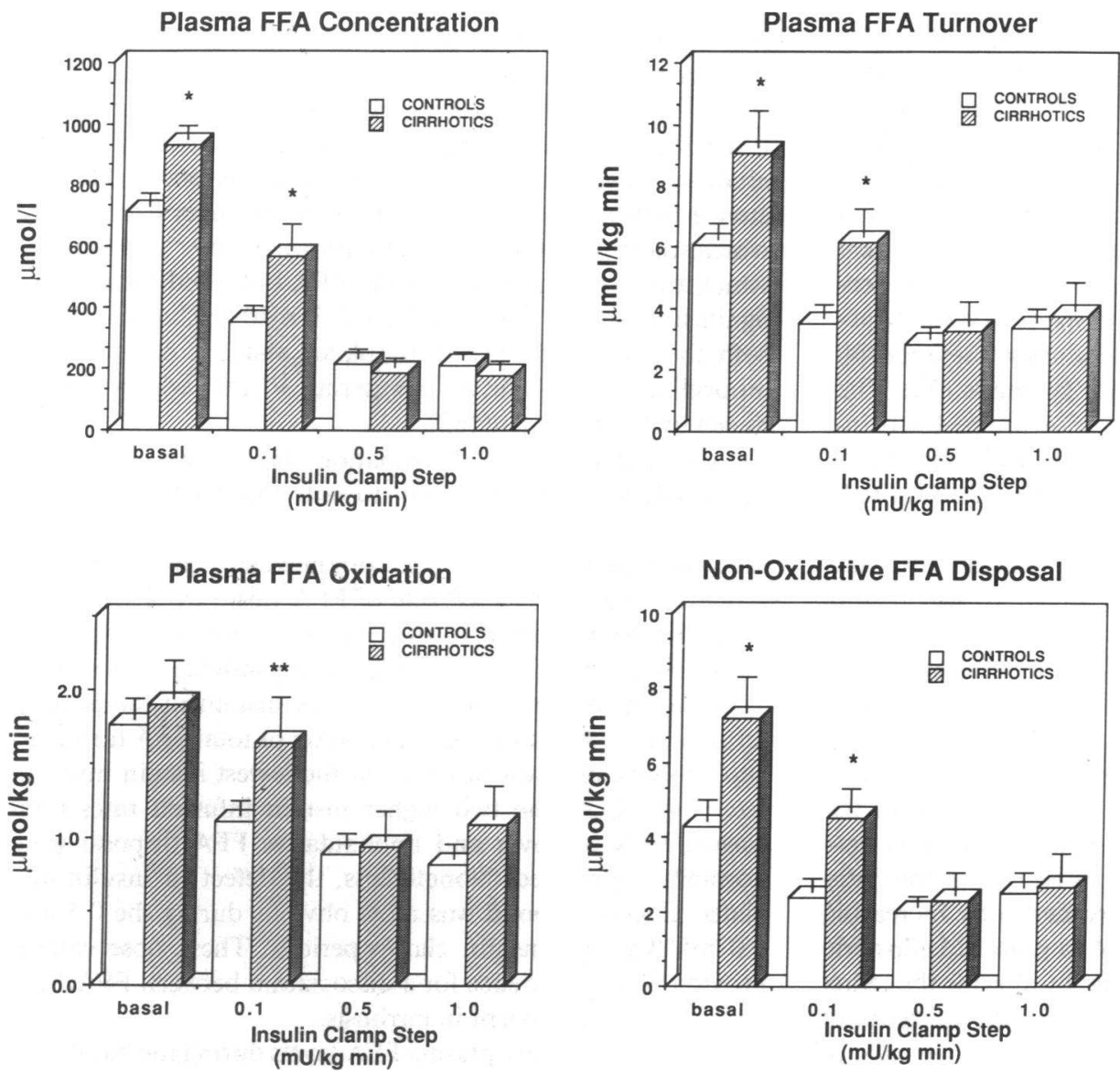

Figure 6. Plasma FFA concentration (upper left panel), plasma FFA turnover (upper right panel), plasma FFA oxidation (bottom left panel), and nonoxidative FFA disposal (bottom right panel) in cirrhotic (cross-hatched bars) and control (open bars) subjects in the basal state and during the three-step insulin clamp. All values represent the mean \pm SEM. ${ }^{*} P<0.01$.

not expect any error in quantitation of total body $R_{\mathrm{a}}$ and $R_{\mathrm{d}}$, and the rate of hepatic glucose production would be estimated quite precisely. Because the $0.1 \mathrm{mU} / \mathrm{kg} \cdot \mathrm{min}$ insulin infusion rate produced an increment in the peripheral plasma insulin conc (mean $\pm 6 \mu \mathrm{U} / \mathrm{ml})$ which is close to the ED $50(5-6 \mu \mathrm{U} / \mathrm{ml})$ for the suppression of hepatic glucose production (28), it is unlikely that our conclusion concerning normal hepatic sensitivity to insulin can be in error. During the two higher insulin infusion rates, when the total body glucose metabolic rate increased to values in excess of $4 \mathrm{mg} / \mathrm{kg} \cdot \mathrm{min}$, the true $R_{\mathrm{a}}$ could be slightly underestimated. However, this would only make the suppression of HGP by insulin appear to be more resistant in the cirrhotic group, and this would only enhance our conclusion that hepatic sensitivity to insulin (at least with regard to suppression of HGP) is not impaired in cirrhosis.

Basal rates of HGP were similar in cirrhotic and control subjects (Fig. 4). Although some investigators have reported a decrease in basal HGP in cirrhosis $(11,37)$, we believe that this most likely reflects an alteration in nutritional balance and associated decrease in lean body mass and/or a diminished glycogen content of the liver related to the more advanced degree of hepatic decompensation (37). It could be argued that a normal rate of basal HGP in the presence of fasting hyperinsulinemia reflects the presence of hepatic insulin resistance. However, it is quite possible that the peripheral hyperinsulinemia, at least in part, results from portocaval/intrahepatic shunting $(45,46)$ and that the insulin concentration that the liver actually sees is diminished. Therefore, we do not wish to overinterpret these results.
In both man $(47,48)$ and animals $(48,49)$, under conditions of euglycemic hyperinsulinemia the majority, 80-90\%, of infused glucose is taken up by muscle $(10,38)$. The liver and splanchnic tissues, like the brain, are insensitive to insulin, at least with respect to stimulation of glucose uptake (47-49). Because adipose tissue accounts for the disposal of $<1-2 \%$ of an intravenous or oral glucose load (50-52), our results indicate that muscle is the primary tissue responsible for the insulin resistance of cirrhosis. In patients with cirrhosis insulin-me-

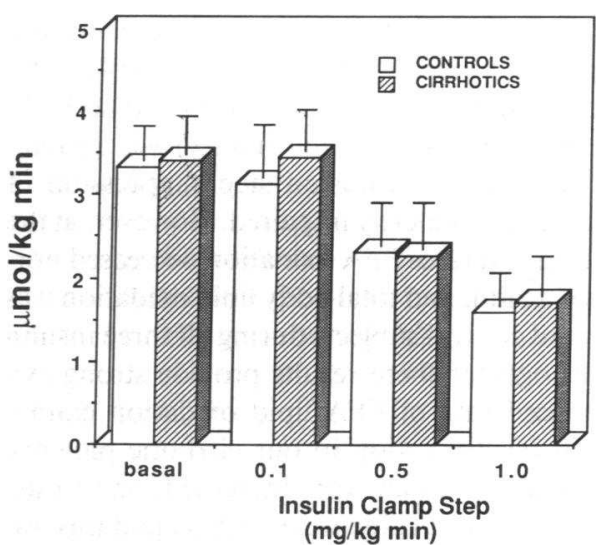

Figure 7. Total body lipid oxidation (measured by indirect calorimetry) in cirrhotic (cross-hatched bars) and control (open bars) subjects in the basal state and during the three-step insulin clamp. All values represent the mean \pm SEM. 
diated glucose disposal is reduced by $\sim 50 \%$ at plasma insulin levels within the high physiological range, $60-120 \mu \mathrm{U} / \mathrm{ml} \mathrm{(5-}$ 8). At supraphysiological plasma insulin concentrations, $>200$ $\mu \mathrm{U} / \mathrm{ml}$, some $(5)$ but not all investigators $(7,8)$ have demonstrated that the defect in insulin action can be overcome. The present results are consistent with previous findings and add two further observations. First, tissue sensitivity to insulin is severely reduced even within the lower, more physiological range of plasma insulin concentrations (35-45 $\mu \mathrm{U} / \mathrm{ml})$. Second, the observed reduction of glucose disposal is entirely accounted for by a defect in nonoxidative glucose metabolism, which primarily reflects muscle glycogen synthesis (52). The enzymatic steps involved in glucose oxidation are perfectly intact in cirrhotic individuals (Fig. 3). Thus, the insulin resistance of cirrhosis appears to involve a specific biochemical abnormality in the muscle glycogen synthetic pathway. Consistent with this Kruszynska et al. (53) have provided evidence that the ability of insulin to activate muscle glycogen synthase is impaired in cirrhosis.

Cirrhosis is characterized by a number of abnormalities in circulating substrate and hormone concentrations including FFA (13-15), glucagon (54), growth hormone (55), norepinephrine (56), and insulin itself (1-8). Moreover, an increase in each of these substrates has been shown to be associated with the development of insulin resistance. According to the "glucosefatty acid cycle" of Randle (12), an elevated rate of free fatty acid oxidation interfers with glucose oxidation by increasing the cellular concentration of acetyl-CoA, a powerful allosteric inhibitor of pyruvate dehydrogenase, and by altering the redox potential of the cell. Much in vivo support for the existence of the glucose/FFA cycle has been provided (28, 57-61). In cirrhosis, plasma FFA levels are increased in the postabsorptive state despite the presence of hyperinsulinemia (13-15). Although, at least in patients with advanced alcoholic cirrhosis, the basal caloric requirements are normal, the nature of the fuels which are oxidized is altered with a shift from carbohydrate to lipid metabolism (13). These observations suggest the possibility that enhanced Randle cycle activity could explain the insulin resistance of cirrhosis. After an overnight fast both the plasma FFA concentration and plasma FFA turnover were significantly increased in our cirrhotic patients, indicating resistance to the antilipolytic effects of insulin. However, the rate of plasma FFA oxidation was not increased (Fig. 5). When considered in light of the elevated FFA flux, the normal rate of plasma oxidation can be viewed as relatively low and argues against the suggestion that increased Randle cycle activity can explain the insulin resistance of cirrhosis. Consistent with this, total body lipid oxidation (measured by indirect calorimetry) was normal. During the lowest dose insulin infusion step suppression of plasma FFA oxidation was modestly impaired. However, at the two higher insulin infusion rates FFA oxidation decreased normally in response to insulin, and total body lipid oxidation was similar in cirrhotic and control subjects during all three insulin clamp steps. Taken together these results provide strong evidence that an increased rate of FFA/lipid oxidation cannot explain the defect in insulin action in our cirrhotic patients. Moreover, if FFA/lipid oxidation were increased, one would expect to find an impairment in glucose oxidation and this was not observed. The increase in lipid oxidation observed by other investigators (13) may reflect altered nutritional intake and a more highly catabolic state. In any case, our results indicate that at a time when insulin resistance is fully established, ele- vated plasma FFA/lipid oxidation cannot explain the defect in insulin action in cirrhotic patients with mild to moderate impairment of liver function. Lastly, it should be noted that the rate of lipid oxidation (measured by indirect calorimetry) exceeded the rate of plasma FFA oxidation (measured by ${ }^{14} \mathrm{C}$-palmitate) during the basal and insulin-stimulated states. The difference between the results obtained by indirect calorimetry (which traces total body lipid oxidation) and by ${ }^{14} \mathrm{C}$-palmitate (which traces oxidation of plasma FFA only) indicates that a significant amount of the lipid which is oxidized by the body in both the basal and insulin-stimulated states is derived from intracellular stores and/or circulating VLDL, which are not traced by ${ }^{14} \mathrm{C}$-palmitate (62).

Although plasma FFA oxidation was normal in our cirrhotic subjects, it is important to note that FFA metabolism was significantly altered. The fasting plasma FFA concentration was increased by $25 \%$ and correlated strongly $(r=0.93, P$ $<0.001$ ) with an elevated rate of FFA turnover (Fig. 6). Because the basal plasma insulin concentration was increased twofold in cirrhotic patients, these results indicate a severe impairment in the antilipolytic action of insulin in the postabsorptive state. An impaired suppression of total FFA turnover, i.e., lipolysis, also was observed at the lowest insulin infusion rate (Fig. 6). At the two higher insulin infusion rates total plasma FFA turnover and nonoxidative FFA disposal were normally suppressed. Nonetheless, the defect in insulin-mediated glucose disposal was most obvious during the 0.5 and $1.0 \mathrm{mU} / \mathrm{kg} \cdot \mathrm{min}$ insulin clamp periods. These observations provide further evidence for a dissociation between FFA/lipid and glucose metabolism in cirrhosis.

Despite the higher plasma FFA levels during the basal state and during the $0.1 \mathrm{mU} / \mathrm{kg} \cdot \mathrm{min}$ insulin clamp step, plasma FFA oxidation was not increased. This is at variance with other insulin-resistant states, i.e., diabetes mellitus and obesity, where the plasma FFA concentration is increased, and this is associated with an increased rate of FFA oxidation $(28,63)$. Thus, all of the increased rate of plasma FFA disposal in cirrhotic patients was accounted for by an increase in nonoxidative FFA disposal, i.e., reesterification (Fig. 6). The failure to observe an increase in whole body FFA oxidation could be explained by an impairment in splanchnic FFA uptake and/or oxidation. Merli et al. have shown that in cirrhotic patients splanchnic oxygen uptake is decreased, and a greater than normal fraction of the oxygen uptake is used for ketone body synthesis, leading to a shortage of oxygen availability for FFA oxidation (64). With respect to the increased basal rate of lipolysis, plasma catecholamines have been shown to stimulate hydrolysis of triacylglycerols in adipose tissue (65). Although the fasting plasma epinephrine level was normal in our cirrhotic patients, the plasma norepinephrine concentration, a potent of stimulator of lipolysis (66), was increased, and it is possible that hypernorepinephrinemia was responsible in part for the increased plasma FFA levels. Alternatively, increased mobilization of depot fat may simply represent resistance to the restraining effect of insulin on lipolysis.

Epinephrine (67), growth hormone (68), and glucagon (69) all impair insulin action in man. However, in agreement with previously reported results (56) the plasma epinephrine concentration was not increased in our cirrhotic patients. Although elevated plasma growth hormone levels in cirrhosis have been reported by some investigators (43), such an increase was not observed in the present study. We did observe a modest 
increase in circulating glucagon levels and an impaired suppression during the insulin clamp, but a significant correlation between plasma glucagon and insulin-mediated glucose disposal could not be demonstrated. Whether the accumulation of some hepatic toxin, which normally is removed by the liver, contributes to the insulin resistance remains a possibility.

Recently, we (70) as well as others (71) have shown that a physiologic increment in the plasma insulin concentration (while maintaining euglycemia) for as little as $72 \mathrm{~h}$ leads to the development of insulin resistance, which is explained entirely by a defect in nonoxidative glucose disposal (70). In the present study both the fasting and glucose-stimulated plasma insulin levels were increased twofold in cirrhosis. Moreover, both the mean insulin response during the OGTT and the fasting insulin concentration were correlated with the severity of insulin resistance during the 0.5 and $1.0 \mathrm{mU} / \mathrm{kg} \cdot \mathrm{min}$ insulin clamp steps (Fig. 5). This observation raises the interesting possibility that hyperinsulinemia per se is responsible for the defect in insulin action. The etiology of hyperinsulinemia in cirrhosis has variably been attributed to enhanced insulin secretion (4), and portocaval/intrahepatic shunting $(45,46)$. Whatever its etiology, the resultant increase in circulating insulin levels causes insulin resistance by impairing nonoxidative glucose disposal. Although some controversy exists concerning insulin binding in cirrhotic patients, most investigators have found both insulin receptor number and affinity to be normal (72). Moreover, if diminished insulin binding were responsible for the insulin resistance of cirrhosis, one would expect proportionate decreases in both glucose oxidation and glycogen synthesis and not an isolated decrease in glycogen formation, as was observed in the present study.

In summary, mild stable cirrhotic individuals are characterized by severe insulin resistance which is explained by a defect in nonoxidative glucose disposal (glycogen synthesis). Although basal plasma FFA turnover is enhanced and fails to suppress normally in response to insulin, FFA/lipid oxidation is not augmented and increased Randle cycle activity cannot explain the defect in insulin action. Our results suggest that hyperinsulinemia per se may be responsible for the insulin resistance of cirrhosis.

\section{Acknowledgments}

The authors wish to thank Ms. Eleanor Andjuar and Syed Hasan for their expert technical assistance. Secretarial support in preparation of the manuscript was provided by Ms. Stella Merla. Dr. A. S. Petrides was the recipient of a postdoctoral fellowship from the Deutsche Forschungsgemeinschaft (Pe 337, 1-1), Federal Republic of Germany. This work was supported in part by National Institutes of Health grant DK 24092, a Veterans Administration (VA) Merit Award, the VA Medical Research Service, the GRECC and Clinical Research Center grant M01-RR-01346.

\section{References}

1. Megyesi, C., E. Samols, and V. Marks. 1967. Glucose intolerance and diabetes in chronic liver disease. Lancet. ii:1051-1055.

2. Cruetzfeldt, W., H. Frerichs, and K. Sickinger. 1970. Liver disease and diabetes mellitus. Prog. Liver Dis. 3:371-407.

3. Johnston, D. G., K. G. M. M. Alberti, O. K. Baber, C. Binder, and R. Wright. 1977. Hyperinsulinism of hepatic cirrhosis: diminished degradation or hypersection? Lancet. i:10-13.

4. Proietto, J., F. J. Dudley, P. Aitken, and F. P. Alford. 1984. Hyperinsulinemia and insulin resistance of cirrhosis: the importance of insulin hypersecretion. Clin. Endocrinol. 21:657-665.
5. Proietto, J., A. Nankervis, P. Aitken, F. J. Dudley, G. Caroso, and F. P. Alford. 1984. Insulin resistance in cirrhosis: evidence for a postreceptor defect. Clin. Endocrinol. 21:677-688.

6. Taylor, R., R. J. Heine, J. Collins, O. F. W. James, and K. G. M. M. Alberti. 1985. Insulin action in cirrhosis. Hepatology 5:64-71.

7. Cavallo-Perin, P., M. Cassader, C. Bozzo, A. Bruno, P. Nuccio, A. M. Dall'Omo, M. Marucci, and G. Pagano. 1985. Mechanism of insulin resistance in human liver cirrhosis. J. Clin. Invest. 75:1659-1665.

8. Iversen, J., H. Vilstrup, and N. Tygstrup. 1984. Kinetics of glucose metabolism in relation to insulin concentrations in patients with alcoholic cirrhosis and in healthy persons. Gastroenterology. 87:1138-1143.

9. DeFronzo, R. A., E. Jacot, E. Jeqier, E. Maeder, and J. P. Felber. 1981. The effect of insulin on the disposal of intravenous glucose: results from indirect calorimetry and hepatic and femoral venous catheterization. Diabetes. 30:10001007.

10. DeFronzo, R. A., and E. Ferrannini. 1987. Regulation of hepatic glucose metabolism in humans. Diabetes Metab. Rev. 3:415-459.

11. Proietto, J., F. P. Alford, and F. J. Dudley. 1980. The mechanism of carbohydrate intolerance of cirrhosis. J. Clin. Endocrinol. Metab. 51:1030-1036.

12. Randle, P. H., P. B. Garland, C. N. Hales, and E. A. Newsholme. 1963. The glucose fatty-acid cycle. Its role in insulin sensitivity and the metabolic disturbances of diabetes mellitus. Lancet. i:785-789.

13. Owen, O. E., V. E. Trapp, G. A. Reichard, Jr., M. A. Mozzoli, J. Montezuma, P. Paul, C. L. Skutches, and G. Boden. 1983. Nature and quantity of fuels consumed in patients with alcoholic cirrhosis. J. Clin. Invest. 72:1821-1832.

14. Riggio, O., M. Merli, A. Cantafora, L. Dibiase, L. Lalloni, F. Leonetti, P.

Miazzo, V. Rinaldi, F. Rossi-Fanelli, G. Tambutano, and L. Capocaccia. 1984.

Total and individual free fatty acid concentrations in liver cirrhosis. Metabolism. 33:646-651.

15. Gunnlaugson, O., and D. Berkowitz. 1987. Individual free fatty acids in patients with liver disease. Dig. Dis. 22:1005-1009.

16. Child, C. G., and J. G. Turcott. 1964. Surgery and portal hypertension. In The Liver and Portal Hypertension. C. G. Child, editor. W. B. Saunders Co., Philadelphia. 50-76.

17. DeFronzo, R. A., J. D. Tobin, and R. Andres. 1979. Glucose clamp technique: a method for quantifying insulin secretion and resistance. Am. J. Physiol. 237:E214-E223.

18. Hawk, P. D. 1947. Kjeldahl method. In Practical Physiological Chemistry. Blakiston, Toronto. 814-822.

19. Coleman, T. G., R. D. Manning, Jr., R. A. Norman, Jr., and A. C. Guyton. 1972. Dynamics of water-isotope distribution. Am. J. Physiol. 223:E1371E1375.

20. Altzuler, N., A. Barkai, A. Bjerknes, B. Gottlieb, and R. Steele. 1975. Glucose turnover values in the dog obtained with various species of labelled glucose. Am. J. Physiol. 225:E1662-E1667.

21. Hales, C. N., and P. J. Randle. 1946. Immunoassay of insulin with insulin antibody precipitate. Biochem. J. 88:137-146.

22. Faloona, G. R., and R. H. Unger. 1974. Glucagon. In Methods for Hormone Radioimmunoassay. B. M. Jaffe and H. R. Berhman, editors. Academic Press, Inc., New York. 317-334.

23. Gordon, P., and J. Roth. 1971. Clinical application of the radioimmunoassay of growth hormone. In Laboratory Diagnosis of Endocrine Diseases. F. W. Sunderman, F. W. Sunderman, Jr., and H. Warren, editors. Green, Inc., St. Louis, MO. 200-205.

24. Passon, P. G., and J. J. D. Peuler. 1973. A simplified radiometric assay for norepinephrine and epinephrine. Anal. Biochem. 51:618-631.

25. Miles, J. R., J. Glassock, J. Aikens, J. Gerich, and M. Haymond. 1983. A microfluorometric method of free fatty acids in plasma. J. Lipid Res. 24:96-99.

26. Steele, R. 1959. Influence of glucose loading and of injected insulin on hepatic glucose output. Ann. NY Acad. Sci. 82:420-430.

27. Cowan, J. S., and C. Hetenyi. 1971. Glucoregulatory responses in normal and diabetic dogs recorded by a new tracer method. Metab. Clin. Exp. 20:360372.

28. Groop, L. C., R. C. Bonadonna, S. Del Prato, K. Ratheiser, K. Zych, E. Ferrannini, and R. A. De Fronzo. 1989. Glucose and free fatty acid metabolism in non-insulin dependent diabetes mellitus. J. Clin. Invest. 84:205-213.

29. Ferrannini, E. 1988. The theoretical basis of indirect calorimetry: a review. Metabolism. 37:286-301.

30. Hagenfeldt, L., J. Wahren, B. Pernow, and L. Raf. 1972. Uptake of individual free fatty acids by skeletal muscle and liver in man. J. Clin. Invest. 51:23242330.

31. Spitzer, J. J., and M. Gold. 1965. Studies on the metabolism of free fatty acids in diabetic and fasting dog. Ann. NY Acad. Sci. 131:235-249.

32. Issekutz, B., H. I. Miller, P. Paul, and W. M. Bortz. 1967. Oxidation of plasma FFA in lean and obese humans. Metabolism. 17:62-72.

33. Wolfe, R. R. 1984. Tracers in Metabolic Research. Alan R. Liss, Inc., New York. 141-147.

34. Cobelli, C., A. Mari, and E. Ferrannini. 1987. Non-steady state: error analysis of Steele's model and development for glucose kinetics. Am. J. Physiol. 252:E679-E689. 
35. Waterhouse, C., N. Baker, and N. Rostami. 1969. Effect of glucose ingestion on the metabolism of free fatty acids in human subjects. J. Lipid. Res. 10:487-494.

36. Anderson, E. C. 1963 . Three compartment body composition analysis based on potassium and water determinations. Ann. NY Acad. Sci. 110:189-210.

37. Owen, O. E., F. A. Reichle, M. A. Mozzoli, T. Kreulen, M. D. D. Patel, I. B. Elfenbein, M. Golsorkhi, K. H. Y. Chang, N. R. Rao, H. A. Hue, and G. Boden. 1981. Hepatic, gut and renal substrate flux rates in patients with hepatic cirrhosis. J. Clin. Invest. 68:240-252.

38. DeFronzo, R. A. 1988. The triumvirate: beta-cell, muscle, liver. A collusion responsible for NIDDM. Diabetes. 37:667-687.

39. Butler, P. C., E. J. Kryshak, W. F. Schwenk, M. W. Haymond, and R. A. Rizza. 1990. Hepatic and extrahepatic responses to insulin in NIDDM and nondiabetic humans. Assessment in absence of artifact introduced by tritiated nonglucose contaminant. Diabetes. 39:217-225.

40. Bell, P. M. R. G. Firth, R. A. Rizza 1986. Assessment of insulin action in insulin-dependent diabetes mellitus using $\left[6-{ }^{14} \mathrm{C}\right]$ glucose, $\left[3-{ }^{3} \mathrm{H}\right]$ glucose, and $\left[2-{ }^{3} \mathrm{H}\right]$ glucose. Differences in the apparent pattern of insulin resistance depending upon the isotope used. J. Clin. Invest. 78:1479-1486.

41. Ferrannini, E., J. D. Smith, C. Cobelli, G. Toffolo, A. Pilo, and R. A. DeFronzo. 1984. Effect of insulin on the distribution and disposition of glucose in man. Insights from physiologic modeling. J. Clin. Invest. 76:357-364.

42. Finegood, D. T., R. Bergman, and M. Vranic. 1987. Estimation of endogenous glucose production during hyperinsulinemic euglycemic glucose clamp. Diabetes. 36:914-924.

43. Molina, J. M., A. D. Baron, S. V. Edelman, G. Brechtel, P. Wallace, and J. M. Olefsky. 1990. Use of a variable tracer infusion method to determine glucose turnover in humans. Am. J. Physiol. 258:E16-E23.

44. Koivisto, V., H. Yki-Jarvinen, J. Kolaczynski, and R. A. DeFronzo. 1990. There is no isotope effect in the disposal of ${ }^{3} \mathrm{H}-3$ labeled glucose. Diabolotogia. 33:168-173.

45. Bosch, J., R. Gomis, D. Kravetz, D. Casamitjana, J. Teres, F. Rivera, and J. Rodes. 1984. Role of spontaneous portal-systemic shunting in hyperinsulinism of cirrhosis. Am. J. Phys. 247:G206-G212.

46. Nygren, A., N. Adnev, L. Sunblad, and K. L. Wiechel. 1985. Insulin uptake by the human alcoholic liver. Metabolism. 34:48-52.

47. DeFronzo, R. A., E. Ferrannini, R. Hendler, P. Felig, and J. Wahren. 1983. Regulation of splanchnic and peripheral glucose uptake by insulin and hyperglycemia. Diabetes. 32:35-45.

48. DeFronzo, R. A., and E. Ferrannini. 1987. Regulation of hepatic glucose metabolism in humans. Diabetes Metab. Rev. 3:415-459.

49. Cherrington, A. D., R. W. Stevenson, K. E. Steiner, M. A. Davis, S. R. Myers, B. A. Adkins, N. N. Abumrad, and P. E. Williams. 1987. Insulin, glucagon, and glucose as regulators of hepatic glucose uptake and production in vivo. Diabetes Metab. Rev. 3:307-332.

50. Bjorntorp, P., and L. Sjostrom. 1978. Carbohydrate storage in man: speculations and some quantitative considerations. Metabolism. 27(Suppl. 2):18531865.

51. Bjorntorp, P., P. Berchtold, and J. Holm. 1971. The glucose uptake of human adipose tissue in obesity. Eur. J. Clin. Invest. 1:480-485.

52. Shulman, G. I., D. L. Rothman, T. Jue, P. Stein, R. A. DeFronzo, and R. G. Shulman. 1990. Quantitation of muscle glycogen synthesis in normal subjects and subjects with non-insulin dependent diabetes mellitus by ${ }^{13} \mathrm{C}$ nuclear magnetic resonance. $N$. Engl. J. Med. 322:223-228.

53. Kruszynska, Y., N. Williams, M. Perry, and P. Home. 1988. The relation- ship between insulin sensitivity and skeletal muscle enzyme activities in hepatic cirrhosis. Hepatology (Baltimore). 8:1615-1619.

54. Sherwin, R., P. Joshi, R. Hendler, P. Felig, and H. O. Conn. 1974. Hyperglucagonemia in Laenec's cirrhosis. N. Engl. J. Med. 290:239-242.

55. Samman, N. A., D. B. Stone, and R. D. Eckhardt. 1969. Serum glucose, insulin and growth hormone in chronic hepatic cirrhosis. Arch. Intern. Med. 124:149-152.

56. Krauns, P., and W. Ruge. 1985. Plasmakatecholaminspiegel bei Lebererkrankungen. Z. Gastroenterol. 23:64-73.

57. Thiebaud, D., R. A. DeFronzo, E. Jacot, A. Golay, K. Acheson, E. Maeder, E. Jecquier, and J. P. Felber. 1982. Effect of long chain triglyceride infusion on glucose metabolism in man. Metabolism. 31:1128-1136.

58. Ferrannini, E., E. J. Barrett, S. Bevilacqua, and R. A. DeFronzo. 1983. Effect of fatty acids on glucose production and utilization in man. J. Clin. Invest. 72:1737-1747.

59. Balasse, E. O., and M. A. Neef. 1974. Operation of the "glucose-fatty acid cycle" during experimental elevations of plasma free fatty acid levels in man. Eur. J. Clin. Invest. 4:247-252.

60. Meylan, M., C. Henny, E. Temler, E. Jequier, and J. P. Felber. 1987. Metabolic factors in the insulin resistance in human obesity. Metabolism. 36:256-261

61. Bevilacqua, S., G. Buzzigoli, R. Bonadonna, L. S. Brandi, M. Oleggini, C. Boni, M. Geloni, and E. Ferrannini. 1990. Operation of Randle's cycle in patients with NIDMM. Diabetes. 39:383-389.

62. Bonadonna, R. C., L. C. Groop, K. Zych, M. Shank, and R. A. DeFronzo. 1990. Dose-dependent effect of insulin on plasma free fatty acid turnover and oxidation in humans. Am. J. Physiol. 259:E736-E750.

63. Groop, L. C., R. C. Bonadonna, D. C. Simonson, A. S. Petrides, M. Shank, and R. A. DeFronzo. 1991. Effect of insulin on oxidative and non-oxidative pathways of glucose and free fatty acid metabolism in human obesity. Am. J. Physiol. In press.

64. Merli, M., L. S. Erikson, L. Hagenfeldt, and J. Wahren. 1986. Splanchnic and leg exchange of free fatty acids in patients with cirrhosis. J. Hepatol. 8:348355

65. Fain, J. N., and J. A. Garcia-Sainz. 1983. Adrenergic regulation of adipocyte metabolism. J. Lipid Res. 24:945-966.

66. Wahrenberg, H., P. Engfeldt, and J. Bolinder. 1987. Acute adaptation in adrenergic control of lipolysis during physical exercise in humans. Am. J. Physiol. 253:E383-290.

67. Deibert, D. F. C., and R. A. DeFronzo. 1980. Epinephrine-induced insulin resistance in man. J. Clin. Invest. 65:717-721.

68. Bratusch-Marrain, P., D. Smith, and R. A. De Fronzo. 1982. The effect of growth hormone on glucose metabolism and insulin secretion in man. J. Clin. Endocrinol. Metab. 55:973-982.

69. Del Prato, S., P. Castellino, D. C. Simonson, and R. A. DeFronzo. 1987. Hyperglucagonemia and insulin mediated glucose metabolism. J. Clin. Invest. 79:547-556

70. Sheehan, P., F. Leonetto, and N. Rosenthal. 1986. Effect of prolonged hyperinsulinemia on glucose metabolism. Diabetes 35(Suppl. 1):16A

71. Rizza, R. A., J. Mandarino, J. Genest, B. A. Baker, and J. E. Gerich. 1985. Production of insulin resistance by hyperinsulinemia in man. Diabetologia. 28:70-75

72. Petrides, A. S., and R. A. DeFronzo. 1989. Glucose metabolism in cirrhosis: a review with some perspectives for the future. Diabetic/Metab Rev. 5:691709. 